\title{
ПРОБЛЕМЫ ПРОТИВОДЕЙСТВИЯ ВЗЯТОЧНИЧЕСТВУ НА СТАДИИ ВОЗБУЖДЕНИЯ УГОЛОВНОГО ДЕЛА
}

\section{PROBLEMS OF COUNTERING BRIBERY AT THE STAGE OF INITIATING A CRIMINAL CASE}

V. Danko

Summary: The aim of the work is to identify the features and place of the stage of initiation of a criminal case on the facts of bribery in the institute of criminal trial. The work is carried out on the basis of special methods of cognition, including historical and legal, logical, formal and legal. The article, taking into account scientific sources and practical experience, examines the stage of initiating a criminal case for crimes under Art. 290-291.2 of the Criminal Code of the Russian Federation. The current norms of criminal and criminal procedural laws in relation to bribery are analyzed. Certain measures are proposed to counteract it.

Keywords: the stage of initiation of a criminal case, criminal law, criminal procedural law, bribery, operational-search activity.
Данько Владимир Александрович

начальник Управления экономической безопасности и противодействия коррупции, Министерство внутренних дел по Республике Хакасия; адъюнкт, Академия управления Министерства внутренних дел России dankovldalks@yandex.ru

Аннотация: Целью работы является выявление особенностей и места стадии возбуждения уголовного дела по фактам взяточничества в институте уголовного судопроизводства. Работа выполнена на основе специальных методов познания, в том числе историко-правового, логического, формально-юридического. В статье, с учётом научных источников и опыта практической работы, рассматривается стадия возбуждения уголовного дела по преступлениям, предусмотренным ст. 290-291.2 Уголовного кодекса Российской Федерации. Проанализированы действующие нормы уголовного и уголовно-процессуального законов применительно к взяточничеству. Предложены определённые меры по его противодействию.

Ключевые слова: стадия возбуждения уголовного дела, уголовное право, уголовно-процессуальное право, взяточничество, оперативно-розыскная деятельность.

Правовая природа данной стадии состоит в том, что должностное лицо, осуществляющее предварительное расследование, при наличии законного повода и основания к возбуждению уголовного дела принимает решение о начале производства по уголовному делу. В случаях их отсутствия, а также при установлении обстоятельств, исключающих производство по уголовному делу - об отказе в возбуждении уголовного дела.

Именно в стадии возбуждения уголовного дела устанавливается и фиксируется юридически значимая информация о признаках преступления, непосредственно реализуется принцип публичности - незамедлительное реагирование государства с целью противодействия преступности правовыми средствами. И, закладывается правовое основание для последующих процессуальных решений, формирования обвинения и определения пределов судебного разбирательства. Здесь отчётливо проявляется связь между процессуальными и не процессуальными формами познания по уголовному делу, которыми выступает оперативно-розыскная деятельность (далее - ОРД). Трудно представить себе начальный этап доказывания при отсутствии предшествующего ему собирания значительного объёма различной оперативной информации. За исключением, пожалуй, только очевидных преступлений, но никак не высоко латентных, к которым наиболее явно относится взяточничество. 
В своём историческом развитии институт «возбуждения уголовного дела» в системе российского уголовного процесса прошёл ряд этапов, из которых можно выделить следующие[1, с. 20]:

- дореволюционный период (1864-1917 гг.);

- ранний советский период (1917-1956 гг.);

- поздний советский период (1956-1991 гг.);

- постсоветский период (1991-2007 гг.);

- современный период (с 2007 г. по настоящее время).

Впервые, стадия возбуждения уголовного дела упоминается 20 ноября 1864 г. в Уставе уголовного судопроизводства при Судебной реформе 1860-1864 гг. С принятием в 1922 г. Уголовно-процессуального кодекса (далее - УПК) Российской Социалистической Федеративной Советской Республики (ст. 96-101)[12] и его редакцией 1923 г. (ст. 91-96)[2, с. 739-740], а также последующих законов, термин «возбуждение уголовного дела» в такой формулировке в УПК РФ [13] закрепился окончательно[3, с. 17].

Представляется, что многочисленные изменения, произошедшие со стадией возбуждения уголовного дела уже в современном периоде, например, изменение количества поводов к его возбуждению, расширение перечня процессуальных и следственных действий возможных до начала предварительного расследования, ограничение полномочий прокурора, фактически не способствовали стабильности правоприменения. А с недавнего времени рассматриваемый элемент уголовного процесса широко обсуждается в части необходимости своего дальнейшего существования.

С учётом высокой латентности взяточничества уже на стадии возбуждения уголовного дела наибольшую актуальность приобретает использование возможностей ОРД. По сути - речь идёт о совершенствовании работы органов, её осуществляющих (далее - субъекты ОРД), указанных в ст. 13 Федерального закона «Об ОРД»[14].

Необходимо отметить, что УК РФ взяточничество первоначально [15] рассматривалось только в виде получения (ст. 290) и дачи взятки (ст. 291). Посредничество во взяточничестве (ст. 291.1)[16] и мелкое взяточничество (ст. 291.2) [17]как преступление введены в уголовный закон только через 15 и 20 лет соответственно. Как понимается это связано с тем, что складывающиеся в обществе отношения развиваются несоизмеримо быстрее, чем нормотворчество.

По уголовным делам по ст. 290-291.1 УК РФ предварительное следствие согласно пп. «а» п. 1 ч. 1 ст. 151 УПК РФ производится следователями Следственного комитета РФ (далее - СК).

По ст. 291.2 УК РФ, в соответствии сп. 1 ч. 3 ст. 150 УПК
РФ, производится дознание дознавателями органов внутренних дел (далее - ОВД) РФ. Но, по письменному согласию прокурора уголовные дела по рассматриваемой статье могут быть переданы для производства предварительного следствия.

Таким образом, в соответствии со ст. 146 УПК РФ, при наличии повода и основания соответствующее должностное лицо (дознаватель ОВД РФ, или следователь, руководитель следственного органа (К) в пределах своей компетенции возбуждает уголовное дело, о чём выносит постановление. Очень важно, что законодатель в основании возбуждения уголовного дела указывает на наличие достаточных данных, а не доказательств. Такими данными могут быть и результаты ОРД.

Но, результаты ОРД по своей правовой природе, способам получения и фиксации, изначально не могут являться доказательствами. Их основная цель, в данном случае, определить основу познавательной деятельности по уголовному делу.

Так, законодатель назвал результаты ОРД именно сведениями (п. 36.1 ст. 5 УПК РФ), которые сами по себе доказательствами не являются, не соответствуя нормативному определению доказательств, будучи полученными вне предусмотренного порядка, и не субъектами, перечисленными в ч. 1 ст. 74 уголовно-процессуального закона[4, с. 6].

То есть, вывод о наличии преступления при принятии решения о возбуждении уголовного дела по фактам взяточничества носит вероятностный характер. Достоверное установление всех обстоятельств его совершения на стадии возбуждения уголовного дела не требуется. Необоснованное же промедление о принятии решения о возбуждении уголовного дела может повлечь за собой утрату или сокрытие следов преступления, утерю доказательств[18].

Неопределённость термина «достаточные данные», установленного ч. 2 ст. 140 УПК РФ как основание для возбуждения уголовного дела, в правоохранительной практике проявляется наличием в производстве субъектов ОРД дел оперативного учёта (или иных оперативных материалов), где должны содержаться зафиксированные сведения, относящиеся к проверяемому факту[5, с. 10].

В целях обеспечения полномочий прокурора по оперативному выявлению нарушений закона, копия постановления о возбуждении уголовного дела незамедлительно направляется прокурору (ч. 4 ст. 146 УПК РФ). Копия может быть представлена как нарочным, так и посредством связи - способом, исключающим внесение изменений в содержание документа (факс, в сканированном виде с использованием сети Интернет и т. п.). 
О возбуждении уголовного дела также незамедлительно уведомляются заявитель и лицо, в отношении которого возбуждено уголовное дело (с момента возбуждения уголовного дела являющееся подозреваемым), что призвано обеспечить своевременное информирование о принятом процессуальном решении лиц, отстаивающих собственные интересы в уголовном деле.

Но, понятие «незамедлительно» является неопределённым и неконкретным в части установления срока. Например, по мнению Н.И. Газетдинова[6, с. 13]направление прокурору постановления о возбуждении уголовного дела должно быть осуществлено не позднее одних суток с момента принятия данного процессуального решения.

Прокурору предоставлено право отменить постановление о возбуждении уголовного дела, если оно признано незаконным или необоснованным, о чём выносится мотивированное постановление, копия которого незамедлительно, но не позднее 24 часов с момента получения материалов, направляется должностному лицу, возбудившему уголовное дело (ч. 4 ст. 146 УПК РФ). Правом отмены постановления следователя СК РФ пользуется также его руководитель (п. 2 ч. 1 ст. 39 УПК РФ).

Постановление о возбуждении уголовного дела может быть обжаловано в суд в порядке ст. 125 УПК РФ, соответственно прокурору (при производстве дознания) и руководителю органа расследования (при производстве предварительного следствия), которые вправе признать его незаконным и необоснованным и отменить.

Следует иметь в виду, что ст. 447 и 448 УПК РФ установлены категории лиц, в отношении которых применяется особый порядок производства по уголовным делам и их возбуждение.

Согласно ч. 5 ст. 20 УПК РФ, уголовные дела о взяточничестве считаются уголовными делами публичного обвинения. По ним уголовное преследование от имени государства осуществляют прокурор, а также следователь и дознаватель (ч. 1 ст. 21 УПК РФ).

В связи с отсутствием в оперативно-розыскном законе понятия ОРМ и каждого из его разновидностей, порядка проведения и отражения их результатов, имеются случаи[7, с. 91-92], когда взяточничество документируется наблюдением, однако фактически проводится оперативный эксперимент, использование которого предусматривает обязательное наличие соответствующего постановления (ч. 7 ст. 8 ФЗ «Об ОРД»). А это приводит к выводу о незаконности действий оперативных сотрудников.

Как считает М.А. Подгрушный, с целью повышения мер по противодействию взяточничеству, ст. 290-291.1 УК РФ следует объединить в одну - «Взяточничество» по аналогии со ст. 204 УК РФ «Коммерческий подкуп», использовать международный опыт[19].

По мнению автора, это сильно «перегрузит» одну статью, так как потребуется применить большое количество составных элементов (частей). Например, сейчас в ст. 204 УК РФ - 8 частей, а в вышеуказанных статьях по взяточничеству - 16 (в 290 - 6, в 291 - 5, в 291.1 - 5). Ссылки на опыт зарубежных стран неубедительны, поскольку не учитывают правовых систем, исторически сложившихся в РФ. Например[20], уголовное законодательство Великобритании не рассматривает субъектом получения, дачи взятки именно чиновника, а предметом взятки может быть какая угодно иная выгода (преимущества) - предложения о трудоустройстве и пр. А нормы США прямо допускают провокацию (операции «жало», «внедрение обратного действия» и т.п.)[21], что никак не может быть приемлемым.

Стоит согласиться, что потребности общества в эффективных мерах противодействия взяточничеству не вызывают сомнений. Однако, общество в большей степени заинтересовано в укреплении гарантий прав личности при осуществлении уголовного судопроизводства.

При таких обстоятельствах разработка новых и совершенствование действующих правовых средств и механизмов борьбы с этим преступным проявлением становятся одними из наиболее значимых и актуальных проблем современного российского права.

Таким образом, стадия возбуждения уголовного дела - это необходимый рубеж или своеобразный «фильтр», но только при обнаружении достаточной совокупности признаков и состава преступления по фактам взяточничества. Она отделяет деятельность процессуальную, связанную с доказыванием, от не процессуальной. Интересно мнение И.Л. Петрухина и И.Б. Михайловской[8, с. 328] которые считают, что производство следственных и вообще всех процессуальных действий возможно только после возбуждения уголовного дела.

В настоящее время учеными уделяется повышенное внимание развитию дальнейших перспектив процессуального использования результатов ОРД, созданию уже на стадии возбуждения уголовного дела значительной основы для будущего доказывания. Высказывалось даже мнение [9, с. 220, 221, 225]о закреплении особого статуса результатов ОРД как повода к возбуждению уголовного дела, предлагался комплекс норм об особенности периода принятия этого процессуального решения после проведения ОРМ. 
Рассматриваемый этап является как возможностью законного добывания значительного числа доказательств (заключения эксперта и специалиста, вещественные доказательства, протоколы следственных действий, иные документы), что регламентировано ст. 144 УПК РФ, обязательством закона в виде обоснованного уголовного преследования для одних[10, с. 76], так и одной из важнейших процессуальных гарантий от неправомерного применения мер уголовно-процессуального принуждения для других.

\section{ЛИТЕРАТУРА}

1. Гаджиев Я.А. Стадия возбуждения уголовного дела в системе российского уголовного судопроизводства: Автореф. дис. канд. юрид. наук. - М., 2015. $34 \mathrm{c}$.

2. Собрание Кодексов Р.С.Ф.С.Р. М.: Юридическое издательство Народного Комиссариата Юстиции Р.С.Ф.С.Р., 1925. - 654 с.

3. Крымов В.А. Начало производства по уголовному делу: от практики к теории // Российский следователь. - 2017. - № 22. - C. 17-21.

4. Гармаев Ю.П. Использование результатов оперативно-розыскной деятельности при расследовании уголовных дел о взяточничестве: практическое пособие / с предуведомл. проф. А.Ю. Шумилова. - М.: Издательский дом Шумиловой И.И., 2005. - 82 с.

5. Васильев Э.А., Прокофьева Т.В. Оперативный эксперимент: основания и условия, исключающие провокацию // Оперативник (сыщик). - 2016. - № 4. C. $9-12$.

6. Газетдинов Н.И. О механизме реализации принципов уголовного судопроизводства на стадии возбуждения уголовного дела // Российский следователь. - 2018. - № 7. - С. 11-14.

7. Уголовно-процессуальная проверка в стадии возбуждения уголовного дела: учебное пособие / А.А. Ларинков, В.А. Шпилюк. - СПб.: Санкт-Петербургский юридический институт (филиал) Академии Генеральной прокуратуры Российской Федерации, 2015. - 160 с.

8. Уголовно-процессуальное право Российской Федерации / Отв. ред. И.Л. Петрухин, И.Б. Михайловская. 3-е изд., перераб. и доп. - М.: Проспект, 2013. $668 \mathrm{c}$.

9. Зажицкий В.И. Результаты оперативно-розыскной деятельности в уголовном судопроизводстве. - СПб.: Юридический центр Пресс, 2006. - 446 с.

10. Козубенко Ю.В. Уголовное преследование. Опыт комплексного исследования. - СПб.: Юридический центр Пресс, 2006. - 259 с.

11. По делу о проверке конституционности отдельных положений Уголовно-процессуального кодекса РСФСР, регулирующих полномочия суда по возбуждению уголовного дела, в связи с жалобой гражданки И.П. Смирновой и запросом Верховного суда Российской Федерации: Постановление Конституционного Суда Российской Федерации от 14 января 2000 г. № 1-П. - URL: http://www.consultant.ru (дата обращения: 30.11.2019).

12. 06 Уголовно-Процессуальном Кодексе (вместе с «Уголовно-Процессуальным Кодексом Р.С.Ф.С.Р.»): Постановление Всероссийского Центрального Исполнительного Комитета от 25 мая 1992 г. - URL: http://www.consultant.ru (дата обращения: 15.09.2019).

13. Уголовно-процессуальный кодекс Российской Федерации от 18 декабря 2001 г. № 174-Ф3. - URL: http://www.consultant.ru (дата 06ращения: 15.09.2019).

14. 06 оперативно-розыскной деятельности: Федеральный закон Российской Федерации от 12 августа 1995 г. № 144-Ф3. - URL: http://www.consultant.ru (дата обращения: 10.09.2019).

15. Уголовный кодекс Российской Федерации от 13 июня 1996 г. № 63-Ф3. - URL: http://www.consultant.ru (дата обращения: 15.09.2019).

16. 0 внесении изменений в Уголовный кодекс Российской Федерации и Кодекс Российской Федерации об административных правонарушениях в связи с совершенствованием государственного управления в области противодействия коррупции: Федеральный закон Российской Федерации от 4 мая 2011 г. № 97-Ф3. - URL: http://www.consultant.ru (дата обращения: 15.09.2019).

17. О внесении изменений в Уголовный кодекс Российской Федерации и Уголовно-процессуальный кодекс Российской Федерации: Федеральный закон Российской Федерации от 3 июля 2016 г. № 324-Ф3. - URL: http://www.consultant.ru (дата обращения: 15.09.2019).

18. Курс уголовного процесса / Под ред. Л.В. Головко. М.: Статут, 2016. - URL: http://www.consultant.ru (дата обращения: 15.09.2019).

19. Подгрушный М.А. Борьба со взяточничеством как коррупционным преступлением в современной России: уголовно-правовые и криминологические аспекты: Автореф. дис. канд. юрид. наук. Саратов, 2014. - URL: http://www.dslib.net/kriminal-pravo/borba-so-vzjatochnichestvom-kak-korrupcionnymprestupleniem-v-sovremennoj-rossii.html (дата обращения: 16.09.2019).

20. Александрова И.А. Взяточничество по законодательству Великобритании и России // Российский следователь. 2011. № 22. URL: http://www.consultant.ru (дата обращения: 10.09.2019).

21. Александров А.С., Кучерук Д.С. Результаты ОРM - база приговора? // Российский следователь. 2012. № 6. - URL: http://www.consultant.ru

(c) Данько Владимир Александрович (dankovldalks@yandex.ru).

Журнал «Современная наука: актуальные проблемы теории и практики» 